\title{
Paraganglioma of the Spermatic Cord: Case Report and Review of the Literature
}

\author{
G. Garaffa ${ }^{1, *}$, A. Muneer ${ }^{1}$, A. Abdel Raheem ${ }^{1}$, A. Freeman ${ }^{2}$, D.J. Ralph ${ }^{1}$, \\ S. Minhas ${ }^{1}$, and R.W. Rees ${ }^{1}$ \\ ${ }^{1}$ Department of Andrology, The Institute of Urology and ${ }^{2}$ Department of \\ Histopathology, University College London Hospitals \\ E-mail: giuliogaraffa@googlemail.com
}

Received October 8, 2008; Revised December 10, 2008; Accepted December 14, 2008; Published December 25, 2008

Paragangliomas rarely involve the genitourinary tract. We present a case of a paraganglioma arising from the spermatic cord and review the literature on the topic.

KEYWORDS: paraganglioma, phaeochromocytoma, cord, adrenal gland

\section{CASE REPORT}

A 69-year-old man presented with unexplained weight loss and malaise. He had undergone a left upper lobectomy for a non-small cell carcinoma of the lung 5 years previously. Fluorodeoxyglucose Positron Emission Tomography (FDG PET) was performed and identified an avid lesion in the right spermatic cord (Fig. 1).

Physical examination confirmed the presence of a 2-cm mobile mass above the right testicle. An ultrasound scan confirmed a highly vascular lesion in the right spermatic cord. His testicular tumour markers and biochemical profile were all normal. He underwent an uncomplicated radical orchidectomy. Examination of the pathological specimen showed a well-circumscribed encapsulated mass in the spermatic cord, separate from the testis and epididymis. This was composed of nests of cells with moderate nuclear pleomorphism and abundant granular eosinophilic cytoplasm, with an intervening rich vascular network. There was no mitotic activity, necrosis, or lymphovascular invasion. Immunocytochemistry showed that the cells were positive for CD56, chromogranin, and synaptohysin, with an intermittent S100 positive sustentacular cell layer. In the absence of a lesion in the adrenals, a diagnosis of a primary paraganglioma of the spermatic cord was made (Fig. 2).

\section{DISCUSSION}

Benign and malignant neoplasms of the spermatic cord are rare[1]. Lipomas, adenomatoid tumours, angiomyxomas, papillary cystoadenomas, and leiomyomas are the most frequently occurring benign neoplasms, while sarcomas and metastases represent the most frequent malignant counterparts[2,3].

Paragangliomas are catecholamine-secreting tumours originating from neuroendocrine cells of the paraganglia of the autonomic nervous system. These cells are characterized by numerous intracytoplasmic neurosecretory granules containing catecholamines or their precursors. They are located in the retroperitoneum 


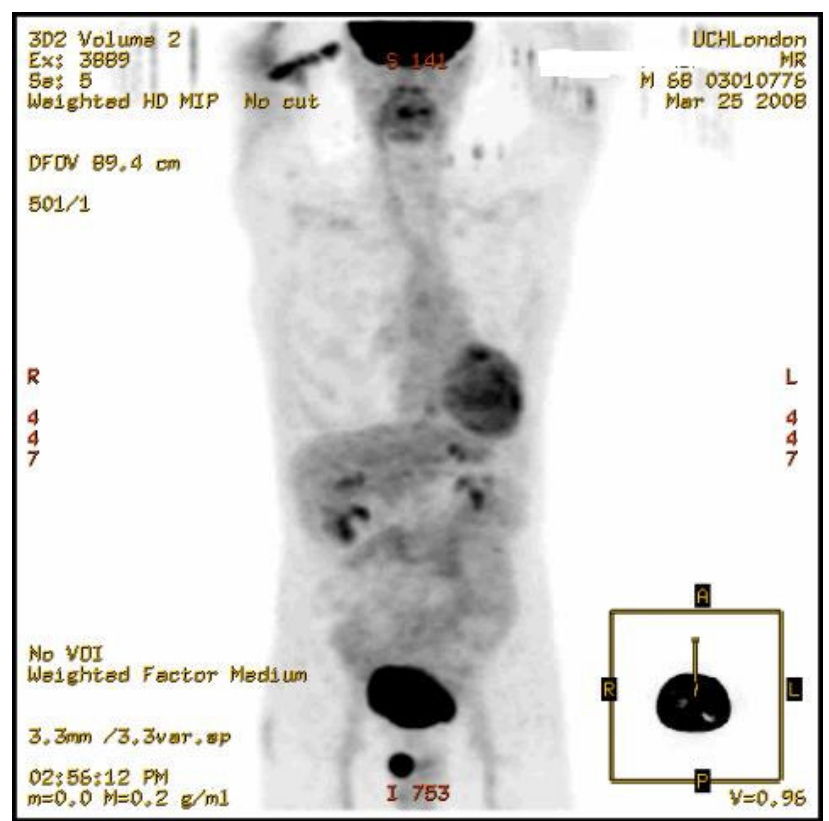

FIGURE 1. FDG PET shows an avid lesion in the right cord and rules out the presence of involvement of the adrenal glands.

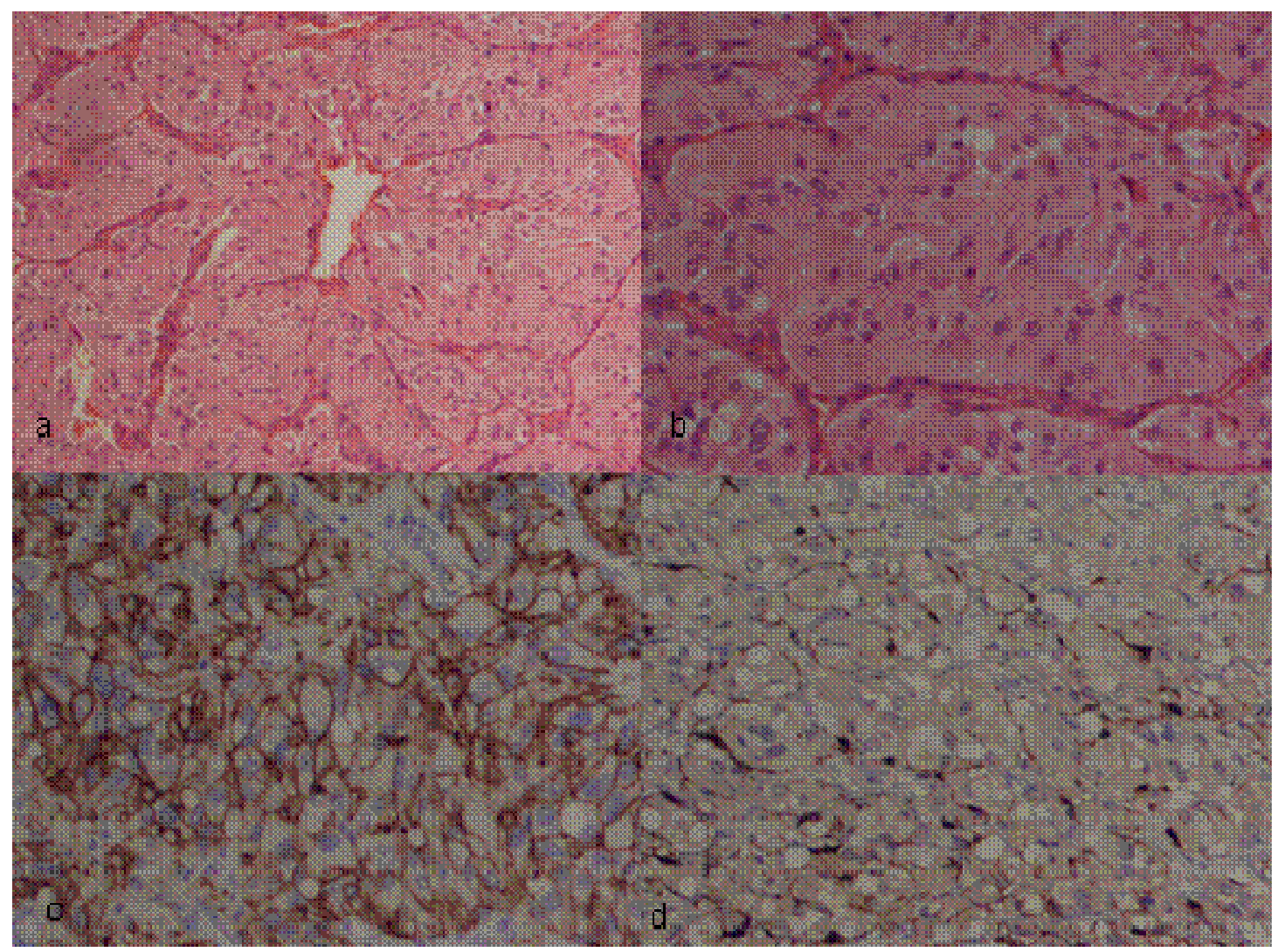

FIGURE 2. (a) A low-power view of the mass showing nested architecture and prominent vascularity (H\&E, $\times 100$ magnification). (b) Cells show moderate nuclear pleomorphism and abundant granular eosinophilic cytoplasm (H\&E, $\times 200$ magnification). (c) Strong CD56 membrane positivity ( $\times 100$ magnification). (d) Scattered S100-positive sustentacular cells $(\times 100$ magnification) 
along the para-aortic axis[4,5,6,7] and are similar to the neuroendocrine cells forming the adrenal medulla. Adrenal remnants have also been reported along the spermatic cord[8]. The microscopic features of tumours derived from these cells are similar, regardless of the location. In the adrenal medulla, the tumours are called phaeochromocytomas, whereas at extra-adrenal sites, they are termed paragangliomas[9,10]. These tumours are benign in around $90 \%$ of cases; the presence of distant metastases is the only reliable criterion to identify malignant cases.

Paragangliomas have been reported in unusual locations, such as the small intestine, gall bladder, lung, and thyroid[11]. Paragangliomas of the urinary bladder are not uncommon and are frequently associated with episodes of hypertension during voiding due to the release to catecholamines[11]. Very few cases involving the spermatic cords previously have been reported[5,7,9].

To our knowledge this is the first case in which an isolated paraganglioma of the spermatic cord has been identified on FDG PET scanning. The absence of haemodynamic symptoms in this patient is probably related to the small size of the tumour and its consequent inability to secrete a sufficient quantity of catecholamines.

\section{REFERENCES}

1. $\quad$ Russo, P. (1991) Urologic sarcoma in adults. Urol. Clin. North Am. 18, 581-587.

2. Weiss, S.W. and Goldblum, J.R. (2001) Lieomyosarcoma. In Einzinger and Weiss's Soft Tissue Tumors. $4^{\text {th }}$ ed. Einzinger, F.M. and Weiss, S.W., Eds. Mosby, St. Louis. pp. 727-748.

3. Liokumovich, P., Herbert, M., Sandbank, J., Schvimer, M., and Dolberg, L. (2002) Cavernous hemangioma of the spermatic cord. Report of a case with immunohistochemical study. Arch. Pathol. Lab. Med. 126, 357-358.

4. Attaran, S.Y., Shakeri, S., and Sobhani, A.R. (1996) Paraganglioma of the spermatic cord: report of a case. J. Urol. 155, 651.

5. Rosai, J. (1989) Ackerman's Surgical Pathology. $7^{\text {th }}$ ed. Vols. 1 and 2. Mosby, St. Louis. pp. $809-813$ and 987.

6. Bacchi, C.E., Schmidt, R.A., Brandão, M., Scapulatempo, R., Costa, J.C., and Schmitt, F.C. (1990) Paraganglioma of the spermatic cord. Report of a case with immunohistochemical and ultrastructural studies. Arch. Pathol. Lab. Med. 114(8), 899-901.

7. Young, I.E., Nawroz, I.M., and Aitken, R.J. (1999) Phaeochromocytoma of the spermatic cord. J. Clin. Pathol. 52, 305-306.

8. Mendez, R., Tellado, M.G., Somoza, I., Liras, J., Sanchez-Abuin, A., Pais, E., and Vela, D. (2006) Ectompic adrenal tissue in the spermatic cord of pediatric patients: surgical implications. Int. Braz. J. Urol. 32(2), 202-207.

9. Tschler, A.S. (2008) Pheochromocytoma and extra-adrenal paraganglioma: updates. Arch. Pathol. Lab. Med. 132(8), 1272-1284.

10. Adler, J.T., Meyer-Rochow, G.Y., Chen, H., Benn, D.E., Robinson, B.G., Sippel, R.S., and Sidhu, S.U. (2008) Pheochromocytoma: current approaches and future directions. Oncologist 13(7), 779-793.

11. Glenner, G.G. and Grimley, P.M. (1974) Tumors of the extra-adrenal paraganglion system (including chemoreceptors). In Atlas of Tumor Pathology. $2^{\text {nd }}$ series. Fasc. 9. Armed Forces Institute of Pathology, Washington, D.C. pp. $81-82$.

This article should be cited as follows:

Garaffa, G., Muneer, A., Abdel Raheem, A., Freeman, A., Ralph, D.J., Minhas, S., and Rees, R.W. (2008) Paraganglioma of the spermatic cord: case report and review of the literature. TheScientificWorldJOURNAL: TSW Urology 8, 1256-1258. DOI 10.1100/tsw.2008.161. 


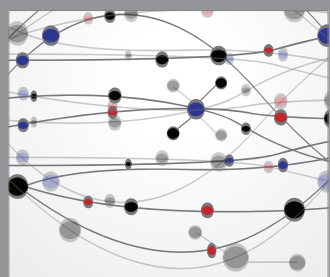

The Scientific World Journal
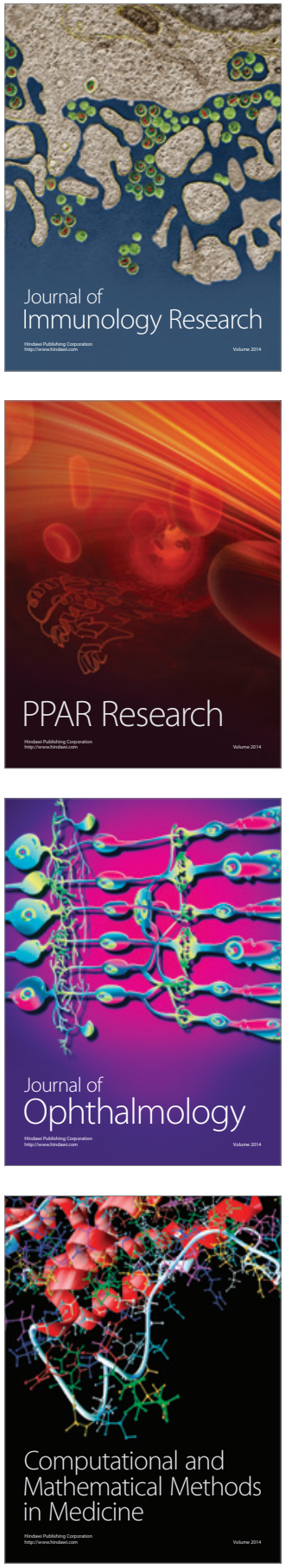

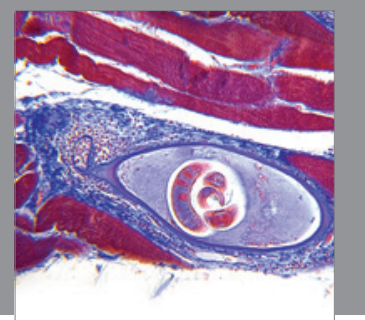

Gastroenterology

Research and Practice
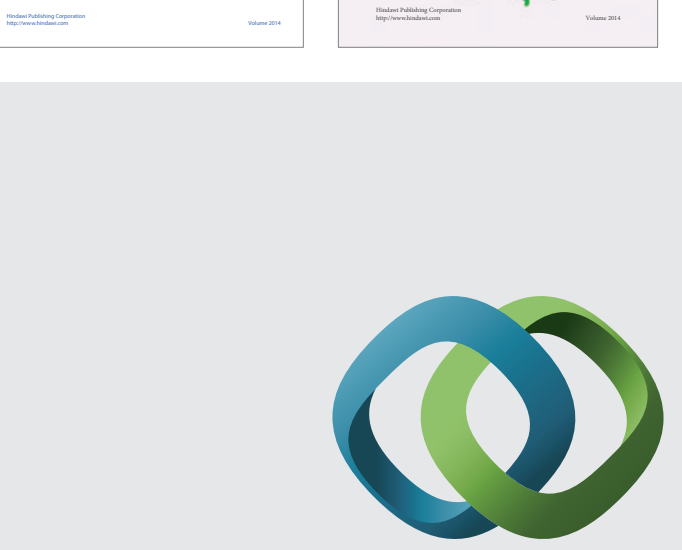

\section{Hindawi}

Submit your manuscripts at

http://www.hindawi.com
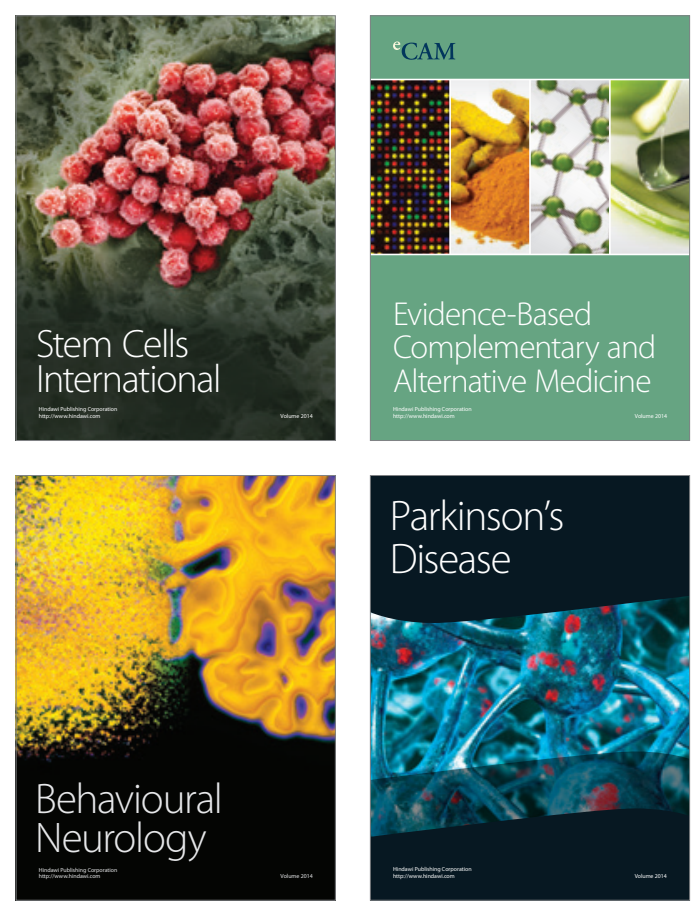

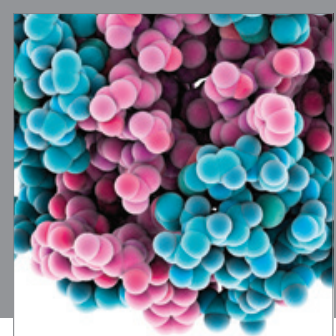

Journal of
Diabetes Research

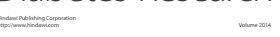

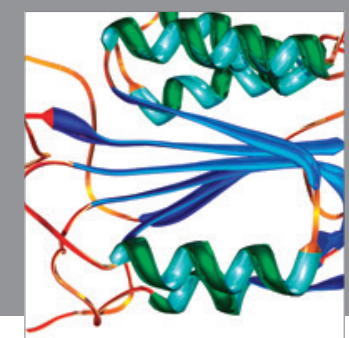

Disease Markers
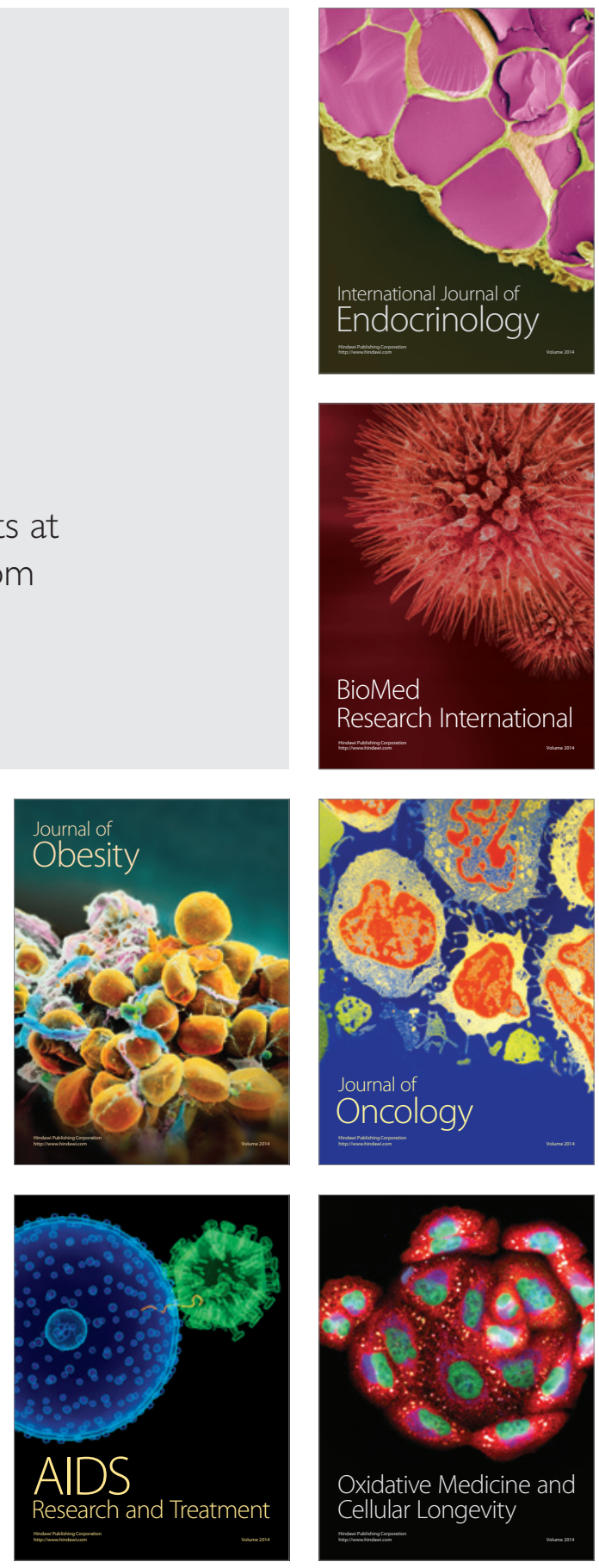